\title{
Career Adaptability and Work Engagement of Millennial Startup Employees
}

\author{
Novia Haryani ${ }^{1}$ \\ ${ }^{1}$ Department of Psychology, Faculty of Education, Universitas Negeri Yogyakarta, \\ Jl. Colombo No. 1 Karangmalang Depok Sleman Daerah Istimewa Yogyakarta 55281 \\ ${ }^{1}$ noviaharyani75@gmail.com
}

\begin{abstract}
This study aims to determine the level of career adaptability and work engagement and the effect of career adaptability on work engagement in millennial generation employees at a startup company. This type of research is ex post facto with a quantitative approach. The population of this study amounted to 34 employees who work at the startup company. This research is a population study; therefore, it uses the entire population of employees. The instrument uses a psychological scale of career adaptability and works engagement. The validity of the research scale uses content validity by expert judgment. The reliability of the research scale was estimated using Cronbach Alpha and composite reliability. The results of the descriptive analysis show that the level of career adaptability and work engagement of millennial generation employees at A startup company is relatively high. The results of multiple linear regression analysis show that: (1) career adaptability affects work engagement, (2) career adaptability concerns and curiosity dimensions affect work engagement, (3) career adaptability dimensions control and confidence have no effect on work engagement.
\end{abstract}

Keywords: career adaptability, work engagement, the millennial generation

\section{Introduction}

The industrial revolution 4.0 is a great force that utilizes information and communication technology to give birth to digital-based businesses such as startup companies (Tazkiyyaturrohmah, 2020). The development of startups in Indonesia is relatively rapid. Judging by the Startup ranking research (2020), Indonesia ranks fifth globally with 2,206 startups. However, the rapid development of startups is comparable to the startup failure rate, which reaches 90\% worldwide (Perdani, Widyawan \& Santoso, 2018). One of the factors that cause startup failure is the human resource factor. Therefore, competent human resources are needed to ensure good company performance (Yanuar \& Sulin, 2019).
Based on this, Bakker and Leiter (2010) suggest that individuals who can show the best performance in their work have a high level of work engagement. Work engagement is a positive and satisfying state, such as states related to selfesteem, strong motivation to do work, and strong feelings to be involved and connected to work (Schaufeli \& Bakker, 2010).

Schaufeli and Bakker (2010:13) state that it can be seen from three aspects, namely vigor, dedication, and absorption, in determining work engagement. Vigor is a high level of willingness to devote energy to the work received, coupled with mental resilience to survive despite getting a difficult job. Dedication is an aspect that can be seen when individuals feel very 
involved in work, have high enthusiasm, are inspired, feel proud of their work, and like to take challenges. Absorption is an aspect in which individuals feel the time is running very fast at work because they are dissolved in their work and have a mindset that can increase total concentration in their work.

Employees with high work engagement can achieve their work goals and organizational goals, and work success. In contrast, employees with low work engagement have a high turnover rate, bad customer treatment, and a lack of innovative ideas (Adi \& Indrawati, 2019; Bakker \& Leiter, 2010). Employees known to experience high turnover intentions and have low engagement are employees of the millennial generation. Millennial generation employees were born from 1985-2000 and were shaped by the technological revolution (Howe \& Strauss, 2000; Othman et al., 2018). According to a survey from Dale Carnegie Indonesia (2017), only 25\% of millennial employees are engaged, and the rest are disengaged. As many as $76.7 \%$ of millennial generation employees only last 1 2 years in their workplace and prefer "jumping bugs". These problems can be suppressed if they have good work engagement.

Two factors influence work engagement, namely job resources and personal resources (Bakker, 2011). Job resources refer to work's physical, social, and organizational aspects to reduce job demands, physiological and psychological costs, achieve work goals, and stimulate growth, learning, and personal development. Personal resources refer to individuals' feelings about their ability to control and impact their work environment. This allows individuals to adapt to changing working conditions. The individual's ability to control and adapt to the work environment refers to the concept of career adaptability.

Career adaptability is defined as the individual's readiness to cope with tasks to prepare for and participate in work roles and adapt to unexpected situations due to changes in work and working conditions (Savickas, 1997). There are four dimensions of career adaptability, which include concern, control, curiosity, and confidence. Concern refers to how an individual is future-oriented and prepares for upcoming career tasks or challenges. Control refers to the responsibility of individuals in shaping themselves and their environment to fulfill what may happen next using self-discipline, effort, and persistence. Curiosity refers to a high curiosity in individuals to think about their abilities in various roles or learn more about jobs that interest them. Then, the confidence dimension refers to the ability and belief of individuals in building selfconfidence to actualize their choices which can then be applied to life (Savickas \& Porfeli, 2012).

Millennial generation employees must have good career adaptability skills because they must prepare for their professional and personal growth to integrate into the global world through new learning models such as adaptability (Othman et al., 2018). In addition, the millennial generation dominates the current workforce.

Considering that millennial generation employees are known as "jump bugs", have high turnover intentions, and have low engagement, it is a threat to the company. However, there is an interesting phenomenon in a particular startup company. Even though most employees at the startup are millennials, the employees can work well and show high spirits. The CEO said that some of the employees seemed enthusiastic about their work to complete it quickly. The startup also received investment from other startup companies. The company's success in getting this investment is also inseparable from the performance of employees who are seen as good by investors. This also impacts the extension of the cooperation 
contract between the client and the company. It is proven that the role of employees as a human resource factor is vital for the company.

The excellent performance of the startup company employees has enabled the company to survive and even recruit new employees for its startup. In addition, companies can open successful boot camps. This is indeed inseparable from the role of employees who participate in helping in developing a boot camp and providing benefits and the company's success in developing one of its business divisions.

This research is necessary to conduct because it looks at the behavior of employees from the millennial generation related to work engagement by looking at personal resource factors such as career adaptability to see how ready they are to face rapid changes in the current 4.0 era industry related to work or unexpected conditions.

The primary hypothesis of this study propose that there is an effect of career adaptability on work engagement. The minor hypothesis proposes that each dimension of career adaptability (concern, control, curiosity, confidence) affects work engagement.

This study is presented to examine the level of work engagement and career adaptability of employees and the effect of career adaptability on the work engagement of millennial generation employees. In addition, to provide advice to companies to improve career adaptability so that employee work engagement can also increase to reduce problems faced by the company.

\section{Methods}

This research uses ex-post facto research. Ex-post facto research is causalcomparative research, in which data are collected after all the events of interest have occurred. In an ex-post-facto research, the researchers select one or more dependent variables and examine the data by going back through time, looking for cause-andeffect relationships, without any treatment and intervention (Azwar, 2018: 10).

This study uses a quantitative approach. The quantitative approach emphasizes the analysis of numerical or numerical data that is processed using statistical methods. All the variables involved must be clearly and measurable (Azwar, 2016: 5).

\section{Research Subjects}

The population of this study is all millennial generation employees, both male and female, who work in a startup company as many as 34 employees. This research is a population study that involves all subjects and studies all subjects directly because the research subject is limited (Azwar 2018: 42).

\section{Instruments}

The procedure carried out in this study is to see the phenomena that often occur in employees at work by comparing the phenomena in the industry/organization where the research is conducted. Furthermore, data collection was carried out by distributing online questionnaires using google forms through social media to obtain quantitative research data.

The data collection technique used in this study uses a psychological scale in a Likert scale consisting of four statements, namely, Very Disappointing, scored 1, to Very Appropriate, scored 4. The term "appropriate" is used to indicate the subject's response because it is considered more relevant in the study. It measured the state of the subject with two variations, namely favorable items and unfavorable items. On favorable items, the value moves from 1-4, while on unfavorable items, the value moves from 4-1.

The work engagement scale used is a modified measurement tool from Titien's UWES (Utrecht Work Engagement Scale). 
The career adaptability scale used is a measuring tool compiled by researchers that refers to aspects of career adaptability according to Savickas (1997) and Savickas and Profeli (2012, 2011).

After item selection, the number of work engagement scale items is 20 items (17 favorable items and three unfavorable items), and the number of career adaptability scales after item selection is 21 items (14 favorable items and seven unfavorable items).

\section{Data Analysis}

The data analysis technique used is descriptive analysis to determine the categories of employee work engagement and career adaptability levels and hypothesis testing using multiple linear regression analysis. Hypothesis testing in this study was not tested for classical assumptions because this research is a population study.

\section{Findings \& Discussion}

The data of this study were obtained from 34 research subjects.

Table 1. Categorization of Work

\begin{tabular}{|c|c|c|c|}
\hline Category & Interval & f & $\%$ \\
\hline Very high & $X>65$ & 11 & $32 \%$ \\
\hline High & $55<X \leq 65$ & 16 & $47 \%$ \\
\hline Moderate & $45<\mathrm{X} \leq 55$ & 5 & $15 \%$ \\
\hline Low & $40<\mathrm{X} \leq 45$ & 1 & $2,9 \%$ \\
\hline Very low & $\mathrm{X} \leq 40$ & 1 & $2,9 \%$ \\
\hline \multicolumn{2}{|c|}{ Total } & 34 & $100 \%$ \\
\hline
\end{tabular}

Based on the table, it is known that most employees have a high level of work engagement with a percentage of around $47 \%$ and a total of 16 employees. Employees with high work engagement tend to have high morale and participate actively in work to achieve work goals, organizational goals and work success (Bakker \& Leiter, 2010). The results of the work engagement category are high because the company implements a pleasant work environment, and there is support from superiors and co-workers so that they can play the role of extrinsic motivation as a predictor of work engagement (Bakker, 2011).

Table 2. Categorization of Career Adaptability Data

\begin{tabular}{|c|c|c|c|}
\hline Category & Interval & f & $\%$ \\
\hline Very high & $X>68,25$ & 12 & $35 \%$ \\
\hline High & $\begin{array}{c}57,5<\mathrm{X} \leq \\
68,25\end{array}$ & 14 & $41 \%$ \\
\hline Moderate & $\begin{array}{c}47,25<\mathrm{X} \leq \\
57,5\end{array}$ & 8 & $24 \%$ \\
\hline Low & $\begin{array}{c}36,75<\mathrm{X} \leq \\
47,25\end{array}$ & 0 & $0 \%$ \\
\hline Very low & $\mathrm{X} \leq 36,75$ & 0 & $0 \%$ \\
\hline \multicolumn{2}{|c|}{ Total } & 34 & $100 \%$ \\
\hline
\end{tabular}

Based on the table, it is known that most employees have a high level of career adaptability with a percentage of around $41 \%$ and a total of 14 employees. Employees with high career adaptability become more adaptable, pay more attention to the future of their work, can control themselves, have high curiosity, and strengthen the self-confidence to pursue what they want (Savickas \& Porfeli, 2012). The results of the career adaptability level can be because many employees take part in mentoring programs developed by companies that can help employees develop their abilities. This is related to the learning environment that can affect career adaptability because the situation in the learning environment can equip individuals to learn according to their career goals (Super \& Thompson 1984 in Patton \& Lokan 2001). 
Table 3. Categorization of Career Adaptability Dimension Data

\begin{tabular}{|l|c|c|c|}
\hline $\begin{array}{c}\text { Career } \\
\text { Adaptability } \\
\text { Dimension }\end{array}$ & Category & $\mathbf{f}$ & $\mathbf{\%}$ \\
\hline Concern & Moderate & 14 & $41 \%$ \\
\hline Control & Moderate & 16 & $47 \%$ \\
\hline Curiosity & High & 12 & $35 \%$ \\
\hline Confidence & Moderate & 16 & $47 \%$ \\
\hline
\end{tabular}

Based on the categorization results above, it is concluded that the employee curiosity dimension is more dominant than the other dimensions in the career adaptability variable. Employees with high curiosity tend to be more realistic in their work-life because they can reflect on the suitability between themselves and the world of work, are interested in trying new things, and explore their careers (Savickas \& Porfeli, 2011). The curiosity category of employees is high because the majority of employees have a high level of education. This is in line with the research of Bocciardi et al. (2017), who found that curiosity was one of the dimensions most influenced by the level of education. The level of education contributes to effectively identifying relevant goals in one's future.

Based on multiple linear regression analysis, it is known that the correlation coefficient $(\mathrm{R})$ is 0.794 , which indicates the career adaptability variable has a strong relationship with work engagement. The coefficient of determination ( $\mathrm{R}$ Square) is 0.630 , which shows that $63 \%$ of career adaptability affects the work engagement variable, and other variables influence the remaining $37 \%$. The effect of career adaptability (simultaneously) on work engagement is quite strong. The categorization results show that employees have high career adaptability, so the behaviors of high career adaptability show positive behavior to support employee performance. Therefore, the career adaptability of employees will affect employee work engagement in the company.

The concern dimension regression analysis results show the beta coefficient value of 0.718 , the $t$-count value of 4.914 , and the effective contribution of $53.6 \%$. The effect of concern on work engagement is quite strong. This is because most employees care about their careers, prepare for their careers, and develop their careers according to their wishes. Therefore, employees who pay more attention to their work and career will show high engagement with their work and organization or company.

The control dimension regression analysis results show the beta coefficient value of -0.003 , the $t$-count value of -0.015 , and the effective contribution of $-0.1 \%$. The effect of control on work engagement is very low or has no effect. This happens because of changing working conditions so that employees are in a state of control. Under control, conditions can make employees impulsive in deciding everything, including work (Marsela \& Supriatna, 2019). Moreover, the work system is often carried out remotely, or WFH does not rule out the possibility that employees often use working hours to do their personal affairs. This behavior can cause employees to procrastinate and ignore good performance as one of the impacts of high work engagement.

The curiosity dimension regression analysis results showed that the beta coefficient was 0.318 , the $t$-count value was 2.332 , and the practical contribution was $17.2 \%$. The effect of curiosity on work engagement is low. This is because some employees work not according to their expertise or the majors they took before. This makes employees less able to reflect on the suitability between themselves and their work so that the effect on work engagement is low.

The regression analysis results of the confidence dimension show the beta 
Haryani

coefficient value of -0.184 , the $t$-count value of -0.938 , and the effective contribution of $-7.7 \%$. The effect of confidence on work engagement is very low or has no effect. This is related to the type of employee work that is not similar to their educational background, causing difficulties in facing challenges and overcoming obstacles in their work. Most of the employees who work not according to their abilities or majors are a contract and outsourced employees. Amalia \& Hadi (2019) stated that contract and outsourcing employees tend to pay less attention to their career growth because they work only to seek experience and financial gain without considering work engagement. This discrepancy with employees' educational background and status makes employees not have high confidence, so it does not affect their work engagement.

\section{Conclusion}

The level of work engagement and career adaptability of the millennial generation employees at A startup company is relatively high. We found an effect of career adaptability on the work engagement of millennial generation employees at a startup company, especially on the dimensions of concern and curiosity. There is no partial influence of the dimensions of control and confidence on work engagement.

\section{References}

Adi, P.R.P. \& Indrawati, K.R. (2019). Perbedaan keterikatan kerja berdasarkan generasi kerja karyawan pada perusahaan berkonsep THK ditinjau dari etos kerja. Jurnal Psikologi Udayana, e-ISSN: 2654 4024; p-ISSN: $23545607,46-57$.
Amalia, R.S. \& Hadi, C. (2019). Pengaruh work design characteristics, career growth, dan psychologycal capital terhadap work engagement karyawan generasi milenial di PT. XYZ. Jurnal Psikologi, 15 (1), 1024.

Azwar, S. (2016). Metode penelitian. Yogyakarta: Pustaka Pelajar.

Azwar, S. (2018). Metode penelitian psikologi (Edisi II). Yogyakarta: Pustaka Pelajar.

Bakker, A.B. (2011). An evidence-based model of work engagement. Current Directions in Psychological Science, 20( 4), 265-269

Bakker, A.B., \& Leiter, M.P. (2010). Work engagement a bandbook of essential theory and research. New York: Psychology Press, 1-20.

Bocciardi, F., Caputo, A., Fregonese, C., et al. (2017). Career adaptability as a strategic competence for career development. European Journal of Training and Development, 41(1), 6782. doi:10.1108/EJTD-07-20160049

Dale Carnegie Indonesia. (2017). Dale Carnegie Indonesia: kaum millenial tidak total bekerja. Accessed on 14 February 2021 dari https://www.dalecarnegie.id/sumber daya/media/media-coverage/dalecarnegie-indonesia-kaum-millenialtidak-total-bekerja/

Howe, N., \& Strauss, W. (2000). Millennials rising: the next great generation. New York, NY: Vintage Books.

Marsela, R.D. \& Supriatna, M. (2019). Kontrol diri: definisi dan faktor. Journal of Innovative Counseling: Theori, Prcatice \& Research, 3 (2), 65-69. 
Othman, R., Kamal, N.M., Alias, N.E., et al. (2018). Positive psychological traits and career adaptability among millennials. International Journal of Academic Research in Business and Social Sciences, 8(9), 1420-1433.

Patton, W. \& Lokan, J. (2001). Perspectives on Donald Super's construct of career maturity. International Journal for Educational and Vocational Guidance, 1:31-48.

Perdani, M.D.K., Widyawan, S. \& Paulus, I. (2018). Faktor-faktor yang mempengaruhi pertumbuhan startup di Yogyakarta. Seminar Nasional Teknologi Informasi dan Komunikasi 2018 (SENTIKA 2018) tanggal 23-24 Maret 2018. Yogyakarta. ISSN: 2089-9815.

Savickas, M.L. (1997). Career adaptability: an integrative construct for life-span, life-space theory. The Career Development Quarterly, 45(3), 247259. doi:10.1002/j.21610045.1997.tb00469.x

Savickas, M. L., \& Porfeli, E. J. (2011). Revision of the career maturity inventory: The adaptability form. Journal of Career Assessment, 19(4), 355374.

https://doi.org/10.1177/106907271 $\underline{1409342}$

Savickas, M. L., \& Porfeli, E. J. (2012). Career Adapt-Abilities Scale: Construction, reliability, and measurement equivalence across 13 countries. Journal of $V$ ocational Behavior, $80(3)$, 661-673. https://doi.org/10.1016/i.jvb.2012.0 $\underline{1.011}$

Schaufeli, W.B., \& Bakker, A.B. (2010). Defining and measuring work engagement: Bringing clarity to the concept. 10-24

Startup Ranking. (2020). Startup ranking countries. Accessed on 12 February 2021 https://www.startupranking.com/cou ntries

Tazkiyyaturrohmah, R. (2020). Tren model bisnis kolaborasi antar perusahaan startup perspektif bisnis islam. Jurnal Penelitian Islam, 14(2), 1-15.

Titien. (2016). Penyusunan dan Pengembangan Alat Ukur Employee Engagement. PSIKOHUMANIORA: Jurnal Penelitian Psikologi, 1(1),113-130.

Yanuar \& Sulin. (2019). Efek mediasi work engagement dalam pengaruh job characteristic dan perceived organizational support terhadap employee performance di bidang it pada perusahaan startup. Jurnal Manajemen Bisnis dan Kewirausabaan, 3 (4), 94-102. 